\title{
COMPARISON OF PAVEMENT STRUCTURES IN TUNNELS
}

\author{
Ivan Rimac \\ Josip Juraj Strossmayer University of Osijek, Faculty of Civil Engineering Osijek, student \\ Miroslav Šimun \\ Institut IGH d.d. Zagreb, PhD. \\ Sanja Dimter \\ Josip Juraj Strossmayer University of Osijek, Faculty of Civil Engineering Osijek, Associate Professor
}

\begin{abstract}
Tunnels pose many fire risks. It is difficult to fight fires in tunnels due to their limited accessibility, the quantity of smoke, and high thermal radiation. Temperatures in tunnel fires can reach $1000^{\circ} \mathrm{C}$, and these fires can spread quickly and persist for long periods, the longest recorded in Europe lasting $53 \mathrm{~h}$. The main requirements of tunnel pavement structures are driving safety and comfort, as well as low construction and maintenance costs. Choosing between using concrete or asphalt pavement structures in tunnels requires the assessment of many criteria, including safety, cost, ecology, and energy use. One must also consider the availability of technologies (finishers) and resources (bitumen or cement), as well as the probability of achieving the required contractor experience level, which impacts pavement management. This paper describes our analysis and process for deciding the pavement structure to be used in tunnels, as well as current European technical regulations for safe traffic flow in tunnels.
\end{abstract}

Key words: tunnels, user safety, concrete pavement, asphalt pavement, multiple criteria analysis

\section{USPOREDBA TIPOVA KOLNIČKIH KONSTRUKCIJA U TUNELIMA}

Sažetak: Tuneli predstavljaju i potencijalna mjesta opasnosti za korisnike u slučaju požara. Borba protiv požara u tunelima teža je zbog ograničene pristupačnosti, količine dima i velikog toplinskog zračenja. Temperature koje se razvijaju tijekom požara u tunelima dostižu i do $1000^{\circ} \mathrm{C}$, vatra se širi vrlo brzo i traje dugo - čak do 53 sata. Osnovni zahtjevi kojima trebaju odgovoriti tunelske kolničke konstrukcije su sigurnost i udubnost vožnje, ali i racionalnost, odnosno isplativost u pogledu investicije i troškova održavanja u eksploatacijskim uvjetima. Kod donošenja odluke o izvedbi betonske ili asfaltne kolničke konstrukcije u tunelima, potrebno je proučiti čitav niz kriterija: sigurnosni, ekonomski, ekološki, energetski. U procesu razmatranja treba sagledati raspoloživost određene tehnologije (finišeri) i resursa (bitumen ili cement), ali i iskustvo kao uvjet postizanja tražene razine uporabne kvalitete, a koja ima utjecaj na gospodarenje kolnicima. U radu je opisana analiza prilikom donošenja odluke o tipu kolnika u tunelima te prikazana postojeća tehnička regulativa europskih zemalja vezana za povećanje sigurnosti prometa u tunelima.

Ključne riječi: tuneli, sigurnost korisnika, betonski kolnik, asfaltni kolnik, višekriterijska analiza 


\section{Introduction}

Modern pavement structures of roads, airports, and other traffic areas have asphalt or concrete surfaces. The main difference between pavement structures with asphalt courses (flexible and semi-rigid structures) and those with concrete slabs (rigid pavement structures) is how they transfer the traffic load and distribute it to the subgrade [1]. In asphalt pavements, all the structure courses transfer the traffic load, evenly distributing the load over the subgrade at $\sim 60^{\circ}$. In concrete pavements, the concrete slab takes most of the traffic load because of its rigidity and large surface area, transferring less load to the subgrade (Fig. 1).

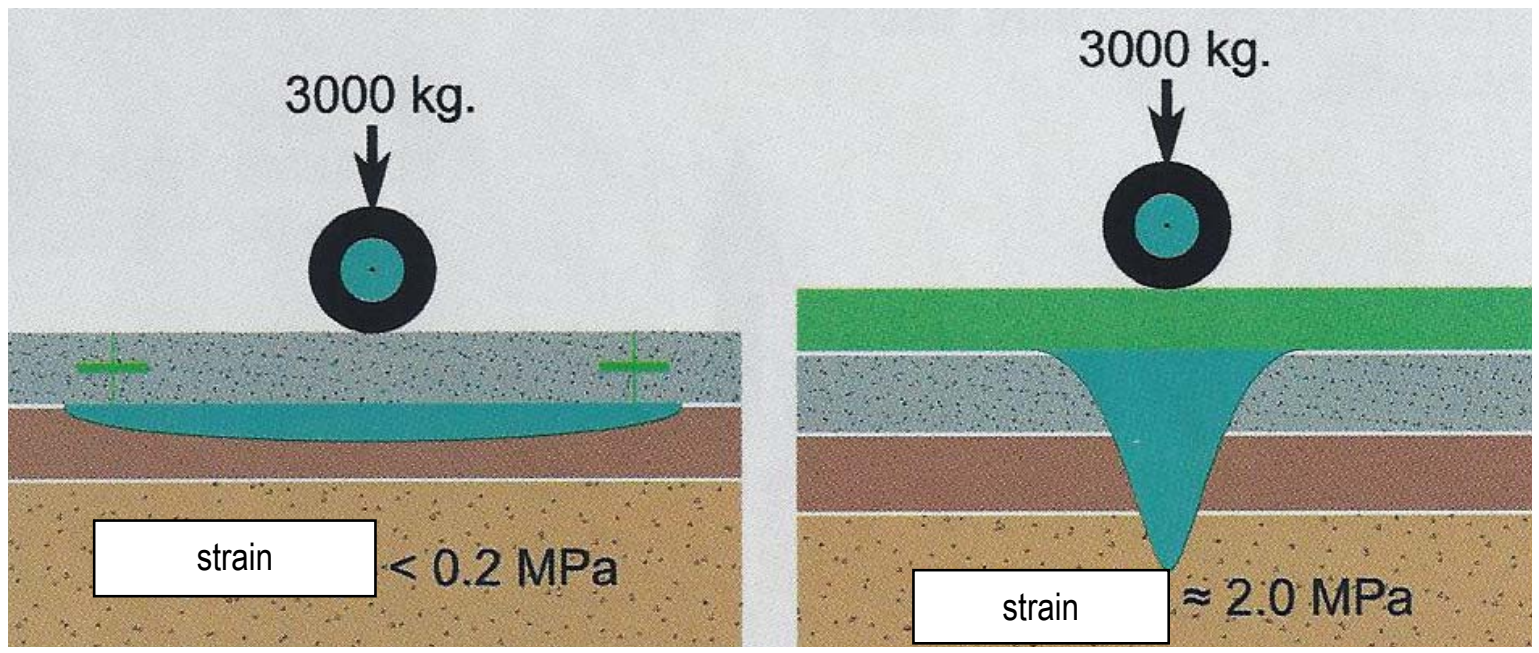

Figure 1. Transfer of load to subgrade [1]: a) concrete pavement; b) asphalt pavement

Because of how concrete pavements transfer traffic load, they are most often used in areas exposed to very heavy and frequent traffic, such as motorways, airports, and container terminals. They are also often used for the pavement slabs of bridges, border crossings, motorway toll stations, waste disposal areas, roundabouts, gas stations, bus stations, and road tunnels [2,3]. The main requirements of pavement structures in tunnels are driving safety and comfort, as well as cost efficiency in building and maintenance.

\section{Comparison of Concrete Pavements with Asphalt Pavements}

Recently, asphalt and concrete pavements have been frequently compared [1,4], mainly because the global financial crisis has heightened the need to choose wise investments. In these comparisons, both the initial construction and maintenance costs must be accounted for. It is also important to assess the environmental impacts and sustainability of asphalt versus concrete, as well as the method used to produce the material (natural or industrial production). To preserve the environment with "green" building practices, we must use materials that can be produced using little energy, emit few or no hazardous gases, and are completely recyclable. Comparisons between asphalt and concrete pavement in tunnels can be made based on several criteria [5], described in Sections 2.1-2.4.

\subsection{Skidding Resistance of the Pavement Structure Driving Surface - Adhesion}

The range of friction coefficients for rubber-asphalt materials is $0.6-0.85$ and for rubber-concrete materials is $0.5-$ 0.80 , indicating rubber adheres relatively uniformly to both asphalt and concrete bases. These data are not significantly different, even for wet driving surfaces. 


\subsection{Cost-Effectiveness of Lighting and Contrast}

Pavement surfaces, especially those in tunnels, require clearly distinguishable markings. Concrete pavements are more easily colored due to their lighter color. In tunnels, reflected light from the pavement surface can illuminate their interiors. Because concrete pavement is lighter colored and more reflective than asphalt, tunnels built with concrete surfaces can be illuminated with less generated light, reducing power consumption. However, safety and visibility in tunnels benefit from stronger contrast among the base, walls, and pavement marks. In this case, the darker asphalt base provides better contrast than the lighter concrete.

\subsection{Longitudinal and Transversal Roughness of Driving Surface}

The roughness of the final pavement course can significantly change the quality of the driving surface from the designed state. Considering surface roughness, concrete and asphalt differ mostly in that concrete pavements are more rigid and require expansion joints. Greater rigidity decreases the roughness of the pavement surface, and the presence of expansion joints (at each $5.5 \mathrm{~m}$ ) roughens the pavement and decreases driving comfort.

\subsection{Traffic Noise}

The main source of traffic noise now comes from contact between vehicle tires and the road surface. Pavement surfaces with high shares of voids and fine-grained materials produce less noise than traditional asphalt and concretes. Concrete pavements increase vibrations because of their higher rigidity, increasing noise. Also, the expansion joints needed in concrete pavements cause dynamic impact every $0.3 \mathrm{~s}$ (at $100 \mathrm{~km} / \mathrm{h}$ ), further increasing noise.

\section{Safety in Tunnels Made from Concrete or Asphalt}

Tunnels pose many fire risks. It is difficult to fight fires in tunnels due to their limited accessibility, the quantity of smoke, and high thermal radiation. Temperatures in tunnel fires can reach $1000^{\circ} \mathrm{C}$, and these fires can spread quickly and persist for long periods: the longest recorded in Europe lasted $53 \mathrm{~h}$. Table 1 shows historical data on tunnel fires on the European road network [6].

Table 1. Fires in European tunnels [6]

\begin{tabular}{|l|c|c|c|c|c|}
\hline \multicolumn{1}{|l|}{ Recent fires disasters in tunnels in Europe } & Tunnel Type & Year & $\begin{array}{c}\text { Duration \& } \\
\text { Temperature }\end{array}$ & Victims & $\begin{array}{c}\text { Vehicles } \\
\text { damaged }\end{array}$ \\
\hline $\begin{array}{l}\text { St. Gotthard } \\
\text { Switzerland }\end{array}$ & $\begin{array}{c}\text { Road }(1 \text { tube }) \\
16.3 \mathrm{~km}\end{array}$ & 2001 & $\begin{array}{c}24 \mathrm{~h} \\
1200^{\circ} \mathrm{C}\end{array}$ & 11 deaths & $\begin{array}{c}10 \text { cars } \\
23 \text { lorries }\end{array}$ \\
\hline $\begin{array}{l}\text { Gleinalm } \\
\text { Austria }\end{array}$ & $\begin{array}{c}\text { Road }(1 \mathrm{tube}) \\
8.3 \mathrm{~km}\end{array}$ & 2001 & $37 \mathrm{~min}$ & 5 deaths & 2 cars \\
\hline $\begin{array}{l}\text { Kitzsteinhorn } \\
\text { Austria }\end{array}$ & $\begin{array}{c}\text { Funicular rail } \\
3.2 \mathrm{~km}\end{array}$ & 2000 & Not known & 155 deaths & 1 shuttle train \\
\hline $\begin{array}{l}\text { Tauren } \\
\text { Austria }\end{array}$ & $\begin{array}{c}\text { Road }(1 \mathrm{tube}) \\
6.4 \mathrm{~km}\end{array}$ & 1999 & $\begin{array}{c}14 \mathrm{~h} \\
1200^{\circ} \mathrm{C}\end{array}$ & 12 deaths & $\begin{array}{c}26 \text { cars } \\
14 \text { lorries }\end{array}$ \\
\hline $\begin{array}{l}\text { Mont-Blanc } \\
\text { France-ltaly }\end{array}$ & $\begin{array}{c}\text { Road }(1 \text { tube) } \\
11.6 \mathrm{~km}\end{array}$ & 1999 & $\begin{array}{c}53 \mathrm{~h} \\
1000^{\circ} \mathrm{C}\end{array}$ & 39 deaths & $\begin{array}{c}10 \text { cars } \\
23 \text { lorries }\end{array}$ \\
\hline $\begin{array}{l}\text { Palermo } \\
\text { Italy }\end{array}$ & Road & 1999 & Not known & 5 deaths & $\begin{array}{c}19 \text { cars } \\
1 \text { coach }\end{array}$ \\
\hline $\begin{array}{l}\text { Eurotunnel } \\
\text { Channel }\end{array}$ & Rail $52 \mathrm{~km}$ & 1996 & $\begin{array}{c}10 \mathrm{~h} \\
1100^{\circ} \mathrm{C}\end{array}$ & 2 injured & 1 shuttle train \\
\hline
\end{tabular}


Ideally, tunnel surfaces should be made from non-combustible, non-toxic pavements. Using this type of surface improves safety, protects the tunnel structure and equipment, and protects the environment. Concrete is non-combustible and not emit toxic gasses when heated, providing maximal safety in fires. Because of concrete's mineral composition, it is inert, stable, and non-combustible. It has a high fire safety factor and does not contribute to fire spreading, easing evacuation of people from the tunnel during fires. Furthermore, concrete pavement is less easily damaged by fire than asphalt. This shortens the repairs when needed, reducing consequent traffic disruptions and accidents. Comparing asphalt and concrete specimens exposed to high temperatures, researchers at Cergy-Pontoise University [7] found concrete superior to asphalt for pavement structures in tunnels for the following reasons (Fig. 2):

- Asphalt is flammable in a temperature range of $428-530^{\circ} \mathrm{C}$, which fires can reach after only 8 min

- Asphalt emits toxic gases after only $5 \mathrm{~min}$; the emitted gases are toxic, some are asphyxiants (CO), and they are carcinogenic

- Asphalt becomes mechanical unstable in fire (the aggregates are still present, but unbound) and can no longer fulfill its main purpose

- Concrete is not flammable and does not emit toxic gases in fire

- Concrete only becomes mechanically unstable when at temperatures exceeding $700^{\circ} \mathrm{C}$ (Fig. 3).

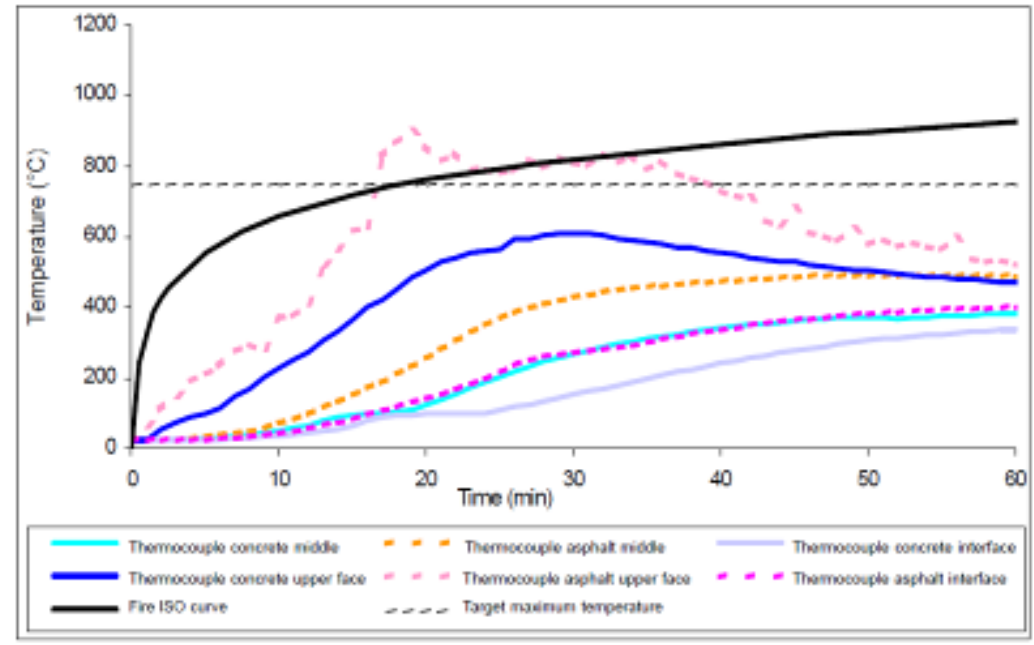

Figure 2. Temperatures of concrete and asphalt over one hour [6]

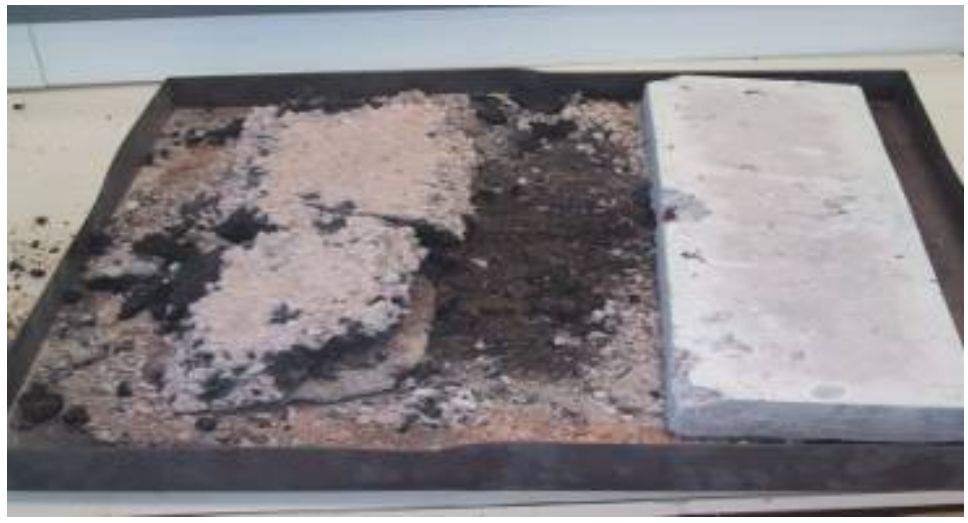

Figure 3. Comparison of asphalt (left) and concrete (right) specimens after heating to $750^{\circ} \mathrm{C}[6]$

Some European countries explicitly require or recommend in their regulations that tunnel pavement be concrete [6]:

- The Austrian Decree of September 2001 related to tunnel projects directives "Projektierungsrichtlinien RVS 09.01.23" [8], requires concrete road pavement in new tunnels longer than $1 \mathrm{~km}$. 
- Slovenia requires concrete pavements in tunnels longer than $1 \mathrm{~km}$.

- In Slovakia, the Ministry of Transport and the Slovak Road Administration have required concrete road pavements in new tunnels since 2001.

- In Spain, public authorities recommend using concrete road pavement in tunnels.

In contrast, in October of 2013, JP Autoceste Federacije BiH d.o.o. Mostar, Bosnia, and Herzegovina formulated instructions [5] requiring the use of asphalt pavement structures in tunnels. They justified the fire resistance of asphalt pavement and its effects on the tunnel structure based on the World Road Association PIARC report "Fire and Smoke Control in Road Tunnels" [9], which reviewed many studies of how pavement structure affected the force of fires. This document concluded that standard asphalt pavements do not significantly decrease fire safety during the first phase of the fire-during which tunnel evacuation occurs-and may be used in tunnels. These instructions [5] presented the conclusions of certain studies/professional papers, including:

- "Performance of pavements in asphalt and concrete in tunnels, particularly in case of fire" (Germany) "There is no reason for which Germany would adopt the Austrian decision not to use asphalt pavements in new tunnels whose length exceeds 1000 metres";

- "Sustainable and Advanced Materials for Road Infrastructure: Review on Reaction to Fire of Pavements Materials" (Samaris) [10] - "Review and investigation of incidents does not indicate an increase of risk due to the selection of pavement structure material, even in cases of catastrophic fires, as shown in the case of the fire in the St. Gotthard tunnel;

- " "Fire behaviour of asphalt pavement in case of road tunnel fire" (France) [11] - "In the fire in the Mont Blanc tunnel and according to the temperatures estimates based on the conducted investigation, asphalt pavement was not the cause of the fire spreading";

- "Fire performance of road tunnels" (France) [10] - "A general rule is to recommend using non-combustible materials for the ceiling and low-combustible materials for the sides, but there are no recommendations for utilisation of pavement materials. Furthermore, it is recommended to pay special attention to the possibility of presence of galleries under the pavement";

- "Brief Introduction to Tunnel Pavements Technologies" (China) [12] - "Coating the concrete or asphalt pavement with an epoxy layer can achieve, among other effects, characteristics of non-combustible materials";

- "Fire performance of asphalt concrete" (France) [13] - "Bitumen-based pavement is not easily combustible, and significant exposure to heat is required to achieve self-combustion. This level of exposure can be achieved only in the immediate proximity of a vehicle already burning. Research results indicate that, in the case of self-combustion of bitumen course, only the surface course participates in fire. The quantity of measured pyrolytic flow is very low compared to that achieved in the case of a burning vehicle. The quantity of produced gases and temperatures due to the burning of asphalt are not great enough to significantly aggravate the situation of users during evacuation."

Existing Croatian regulations do not discuss concrete pavement, and these pavements are not widely used outside of toll stations, gas stations, border crossings, and some bus terminals and bays. In Croatia over the last 20 years, asphalt pavements have been used in tunnels, for which no reported safety problems have been caused by fire. When choosing a pavement type for use in a tunnel, it is important to provide a fire-alarm system, establish a fire-extinguishing procedure, and plan a passenger evacuation strategy.

\section{Construction and Maintenance of Pavement Structure in Tunnels}

The construction cost of concrete and asphalt pavements can be calculated by assessing the individual tenders submitted by contractors. In our region, concrete pavement is $\sim 30 \%$ more expensive than asphalt pavement. Concrete pavements have longer lifespans (40 years), almost twice those of asphalt pavements, but their construction and maintenance costs are higher. Croatia has never used concrete pavements in tunnels, making it difficult to estimate the exact maintenance cost. Maintenance of pavement structures can be very costly, so it is important to select the most appropriate technology, technical solutions, and materials. 
The method of repair for concrete pavement depends on the defects present, such as cracks, deterioration of expansion joints, and surface defects). For partial repairs of non-reinforced slabs through their whole thickness, additional expansion joints must be introduce, which can roughen the driving surface. For partial repairs of slabs up to one third of the thickness at their expansion joints or damaged borders, they are performed using materials with high rigidity and low shrinkage or materials based on epoxy resins and special cements. These repairs require quality materials, leading to high cost. In contrast, asphalt pavements with local defects can be repaired inexpensively with a simple, high-quality connection between the new and the old asphalt, applying classical technology and materials. Asphalt pavement has an estimated lifespan of 7-10 years, after which it is recommended to remove the wearing course and to construct a new one.

For the Corridor Vc motorway through the Federation of Bosnia and Herzegovina, including the GoricaBilješevo section with the "Vijenac" tunnel with two parallel pipes of length amounting to $3.2 \mathrm{~km}$, concrete pavement was contracted to match the structure's design. However, the investor ordered an amended pavement structure to be designed in order to comply with Mostar instructions [5], which required asphalt pavement (Fig. 4). The investor also ordered all designers, supervision teams, and contractors to use asphalt pavements in tunnels to comply with current standards and regulations, on all sections being designed, being prepared for construction, or being constructed. The pavement structures in tunnels will have identical composition and dimensions as those on open routes, outside the tunnels, in compliance with "Instruction No. 14 for designing and execution of pavement structures on motorway route":

- Wearing Course: SMA 11s (SBM11s), PmB 45/80-65, Eruptive

- $\quad$ Binding Course: AGNS 22s, PmB 45/80-65, Carbonate

- $\quad$ Bearing Course: AGNS 32s or AGNS 22s, B 35/50, Carbonate

- Cement-stabilized course (thickness of $20 \mathrm{~cm}$ ), complying with the requirements of current technical conditions

- Unbound Mechanical Compacted (Sub-Base) Course: NNS 0/45 mm, f5, Ev2 $\geq 120$ MPa.

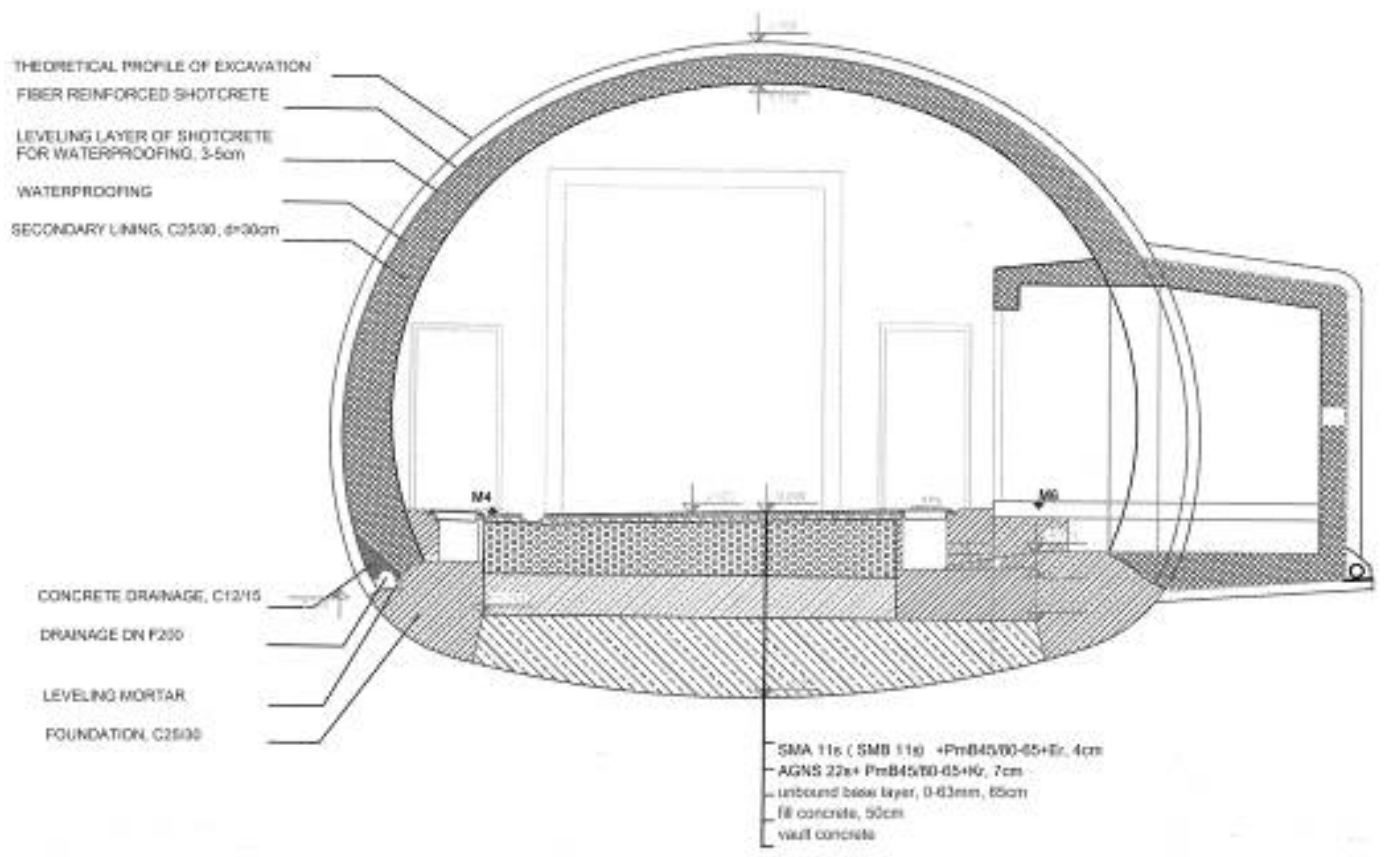

Figure 4. Cross-section D-D of the "Vijenac" tunnel in the Corridor Vc in FB\&H

The minimum thickness of the bearing unbound course of the pavement structure (sub-base) is $25 \mathrm{~cm}$. In case the tunnel structure contains an invert, the space between the pavement structure and the invert is filled with $25 \mathrm{~cm}$ of filter fill and then with fill made of $0 / 63 \mathrm{~mm}$ stone mixture, whose grain-size distribution corresponds to the sub-base mixture with $d_{\max }=63 \mathrm{~mm}\left(U=d_{60} / d_{10}\right.$ of $\left.15-80\right)$ and fine-particle loading of up to $12 \% \mathrm{~m} / \mathrm{m}$ (category f12) and whose mechanical properties meet the criteria of sub-base mixtures. After filling and leveling, the filter fill is compacted using light machinery to avoid damaging the drainage pipe. Geotextile is then placed 
over the filter fill, overlapping in the filling direction of the first fill layer to a thickness of $25 \mathrm{~cm}$. The fill material must be filled and leveled from the front to avoid disturbing the filter fill, geotextile, or drainage pipe. The first fill layer must achieve $\sim 75 \%$ of the bearing level of the subgrade; i.e., $\operatorname{minEv}_{2}=60 \mathrm{MPa}$. The final bearing level must achieve $\mathrm{minEv}_{2}=80 \mathrm{MPa}$.

\section{Conclusion}

Concrete is environmentally friendly, as its production and use requires less energy and thus emits less $\mathrm{CO}_{2}$, and concrete batching plants produce less atmospheric pollution than asphalt plants. Concrete is non-combustible and safe in fires, improving traffic safety in road tunnels. However, concrete pavements are costly and more demanding in execution and maintenance technologies. Choosing between using concrete or asphalt pavement structures in tunnels requires the assessment of many criteria, including safety, cost, ecology, and energy use. One must also consider the availability of technologies (finishers) and resources (bitumen or cement), as well as the probability of achieving the required contractor experience level, which impacts pavement management.

\section{References}

[1] Rajzer R.; Kolnici B. 2012: osnovni tipovi, povijesni razvoj i primjena u razvijenim državama svijeta i u Hrvatskoj, Mineral, Volumen 6, pp. 26-31 (in Croatian)

[2] Rimac I. 2012: Usporedba asfaltnih i betonskih zastora, diplomski rad, Sveučilište Josipa Jurja Strossmayera u Osijeku, Građevinski fakultet Osijek, mentor: izv. prof. dr. sc. Sanja Dimter, pp. 108 (in Croatian)

[3] Lakušić S.; Šimun M.; Rajzer R. 2011: Primjena betonskih kolnika u Hrvatskoj, Projektiranje prometne infrastrukture, Dani prometnica 2011, Građevinski fakultet Sveučilišta u Zagrebu, Zagreb, pp. 275-320 (in Croatian)

[4] Bjegović D. 2007: Betonski kolnici - prednosti i mane, Almanac Savremena građevinska praksa, Novi Sad, pp 7-18 (in Croatian)

[5] Upute za projektovanje i izvođenje kolovoznih konstrukcija u tunelima, Set uputa za projektovanje, nabavku, ugradnju i održavanje elemenata, objekata ili dijelova objekata na autocestama, Javno preduzeće Autoceste Federacije Bosne i Hercegovine, No.: 01-5871-1/13. Mostar (in Croatian)

[6] Improving fire safety in tunnels: The concrete pavement solution, Concrete road pavement improves tunnel safety CEMBUREAU, 2004. Accessed 13 May 2012.

Available on: $h$ ttp://www.febelcem.be/fileadmin/user_upload/autres-publications/en/firesafety.pdf

[7] Noumowe A. 2003: Characterisation of asphalt exposed to high temperature: Application to fire case of asphalt pavement, Cergy-Pontoise University (English version)

[8] RVS 09.01.23: Projektierungsrichtlinien - Bauliche Gestaltung - Tunnel, Innenausbau, Bundesministerium für Verkehr, Innovation und Technologie, Wien, 2001

[9] Comité technique 5 Tunnels routiers (Technical Committee 5 Road Tunnels), Systems and equipment for fire and smoke control in road tunnels, PIARC Ref. 05.16.BEN, 2007

[10] Jofre C.; Romero J.; Rueda R. 2010: Contribution of concrete pavements to the safety of tunnels in case of fire, European Concrete Paving Association.

[11] Jacobs J.-P. 2007: Comprehensive fire protection and safety with concrete, European Concrete Platform.

[12] The 4th IACIP Annual Workshop, The Fourth US-China Workshop on Research and Education Collaboration in Transportation Infrastructure, 2014

[13] European Asphalt Pavement Association, Asphalt pavements in tunnels, Brussels, Belgium, 2008 